\title{
The impact of territorial policies on the distribution of the creative economy: tracking spatial patterns of innovation in Slovenia
}

\author{
JANi KOZINA ${ }^{1}$ and DAvid BOLE ${ }^{1}$
}

\begin{abstract}
The creative economy as an alternative pathway for industrial decline was first introduced into practice in metropolitan regions of the Global North. Since then, it has gradually spread out to other highly urbanized areas of the Global South and transitional areas such as post-socialist European countries. Numerous studies tried to explain structural conditions and suggested policies to attract, retain and release creative potentials. However, the focus on promotion of the creative economy is still on large cities and sectoral policies by emphasizing economic, social and legislative issues of the creative labour. There is little evidence about how territorial policies shape the development of the creative economy, especially in medium-sized and small towns outside the reach of the agglomeration areas. The aim of this paper is to study the impact of territorial policies on the distribution of the creative economy in Slovenia as an example of the post-socialist country. By analysing spatial-temporal trends of patents, we track patterns of innovation between 1975 and 2014 in the urban system. A central focus is given to examine changes in urban hierarchy, i.e. relationships between Ljubljana as the capital and the only large city in the country, regional centres and small towns. The spatial-temporal analysis of patents granted in Slovenia confirmed the linkages between territorial innovation systems and policies. The main findings show that innovation has become more evenly distributed across space, which can be attributed to long tradition of polycentric spatial development in times of Yugoslavia and more recent territorial policies favouring further dispersion of the local self-government system in Slovenia.
\end{abstract}

Keywords: cultural and creative industries, territorial innovation systems, intellectual property, patents, urban development, urban hierarchy, policentricity, small and medium-sized towns, Central and Eastern Europe

\section{Introduction}

The creative economy as an alternative pathway for industrial decline was first introduced into practice in metropolitan regions of the Global North. Since then, it has gradually spread out to other highly urbanized areas of the Global South and places in transition such as post-socialist European countries (Chapain, C. et al. 2013; Stryjakiewicz, T. et al. 2014; SChlesinger, P. 2016). Numerous studies tried to explain structural conditions and suggested policies to attract, retain and release creative potentials (LANDRY, C. 2000; Florida, R. 2002; Boschma, R.A. and Fritsch, M. 2009; Musterd, S. and Murie, A. 2010; Musterd, S. and Kovács, Z. 2013).
However, despite providing substantive contributions to the discussion on the creative economy, its geography and support mechanisms, the literature still contains some gaps because it is quite biased towards advanced economies (Hong, J. et al. 2014) and/or large cities and metropolitan areas (KozInA, J. and Bole, D. 2017). There is less research trying to identify specifically how different national understandings, economic systems, and geographic and institutional contexts influence the way creative economy works or the type of territorial policies implemented to support it (Chapain, C. et al. 2013). Furthermore, in comparison with increasing empirical analysis of global urban network, relatively little has been done to examining urban hierarchy

\footnotetext{
${ }^{1}$ Research Centre of the Slovenian Academy of Sciences and Arts, Anton Melik Geographical Institute; Novi trg 2, 1000 Ljubljana, Slovenia. Correspondent author's e-mail: jani.kozina@zrc-sazu.si
} 
and changing patterns of urban networks at national levels from the perspectives of creativity and innovation (Lu, L. and HuANG, R. 2012). The latter is especially true for post-socialist European countries that have recently undergone significant changes in terms of economic, social and spatial restructuring. At the beginning of the 1990s, many postsocialist cities were almost complete deserts in terms of innovation (STRYJAKIEWICZ, T. et al. 2014). Nowadays, Central and Eastern Europe (CEE) still performs among the worst on the European Innovation Scoreboard, although regional 'pockets of excellence' can be identified in some Moderate Innovator countries (Member States where performance is between 50 per cent and 90 per cent of the EU average) such as Prague in the Czech Republic or the Bratislava region in Slovakia (Hollanders, H. and Es-SADKI, N. 2017). However, we need a much better insight into the national spatial dynamics and territorial policies to support emerging creative economy and innovation in the postsocialist urban context.

The aim of this paper is to study the impact of territorial policies (such as regional plans, local self-government legal acts or strategies of spatial development) on the distribution of the creative economy in Slovenia as an example of the post-socialist country. By analysing spatial-temporal trends of patents, we would like to track patterns of innovation between 1975 and 2014 in the urban system. A central focus is given to examining changes in urban hierarchy, i.e. relationships between Ljubljana as the capital and metropolitan city, regional centres and small towns. Due to long tradition of polycentric spatial development in times of Yugoslavia and more recent territorial policies favouring further dispersion of the local self-government system, we hypothesize that patterns of innovations are becoming more evenly distributed across space. A peculiarity of the Slovenian urban system is the dominance of smaller towns due to traditionally dispersed settlement system and polycentric policies during the (post)socialist era. International urban-rural typologies usually place Slovenia among the least urbanized European countries; according to the latest methodology, Slovenia is the second most rural country in Europe right behind Lithuania with 51.6 per cent of rural residents (Eurostat 2017). In this paper, we attempt to make two theoretical contributions. First, we try to add to the discussion if specific national territorial policies influence the distribution of the creative economy by investigating the spatial patterns of innovation. Second, we add to the theoretical debate of the creative economy by involving the concept of territorial innovation systems as a proxy for measuring a spatiality of the creative economy.

\section{Theoretical background}

\section{Conceptualizing creative economy and innovation}

The origins of the creative economy should be sought in changing economic circumstances of post-World War II when developed industrialised countries increased productivity, started moving traditional manufacturing to developing countries and entered post-industrial age by favouring services, knowledge, creativity, and innovation (Bell, W. 1973; Scott, A.J. and Storper, M. 2014). Strongly influenced by the movements around the "cultural turn" that shifted attention away from the Marxist tradition towards culture so-called "cultural industries" gained importance in the 1980s (GARNHAM, N. 2005). They refer to the traditional cultural economics and to forms of cultural production characterised by a symbolic element and encompass many fields, from art to movies, music and others (LAzzeretTI, L. et al. 2018). Since the 1990s, another turn - the "creative turn" - denoted the dawn of a new era in political and academic domains by constructing the creative industries and latterly, the creative economy, as a policy object that can be managed to secure primarily economic and sometimes social outcomes so as to increase 
competitiveness (Schlesinger, P. 2016). The focus of cities, regions or countries across the world thus redirected to the importance of creativity and innovation in fostering development with the emergence of highly interrelated concepts such as creative industries, creative economy and the creative class (Chapain, C. et al. 2013).

Despite its raising importance and popularity, the creative economy is a vague concept encompassing numerous inconsistent definitions (BogGs, J. 2009). The most recent bibliometric analysis distinguishes between three main streams of the creative economy research evolving around the concepts of 1) cultural and creative industries, 2) the creative class, and 3) the creative city (LAZZERETTI, L. et al. 2018). It is quite commonly accepted that cultural and creative industries lay at the heart of the creative economy (for a review see Collins, P. and Cunningham, J.A. 2017). Although cultural and creative industries may be difficult to measure, there seems to be a wide agreement about intellectual property to define them (see Garnham, N. 2005; Newbigin, J. 2010). The creative economy can be understood as 'financial transactions in creative products, whose economic value is secured through copyright, design, trademark and patents', and therefore includes the arts, media, new media, design and architecture (creative industries) along with the sciences, engineering and technology sectors (knowledge-intensive industries) (HowkINs, J. 2001; Cunningham, S.D. 2007).

The emerging economic activities adopted by competitive cities and regions can thus be attributed to creative and knowledge-intensive industries (BontJe, M. and Musterd, S. 2009; Musterd, S. and Murie, A. 2010; Bontje, M. et al. 2011; Musterd, S. and Gritsai, O. 2012; Musterd, S. and Kovács, Z. 2013). The role of the creative economy is to connect the creative sector to national and regional innovation systems and thereby move it into the sphere of research-based, knowledge-intensive industry policy (CUNNINGHAM, S.D. 2007; European Commission 2010; Hong, J. et al. 2014). Compared to creative indus- tries, which are limited to specific sectors, the creative economy is used to encapsulate also their spill-over effects on a wide range of economic and social contexts (European Commission 2010; Kern, P. 2015). The creative economy is thus directly contributing to innovation (BAKHshi, H. and McVittie, E. 2009; Lee, N. and Rodríguez-Pose, A. 2014; FlORIDA, R. et al. 2017) through creative inputs, such as ideas for new products, supplementary products and services or marketing support for product innovations (MüLLER, K. et al. 2009). From this perspective, innovation can be viewed as an integral part of knowledge-intensive industries and thus the creative economy.

\section{Territorial systems of innovation}

The systems of innovation have been categorized into national innovation systems, regional innovation systems and sectoral innovation systems with the first two relying on a spatial dimension (Markatou, M. and ALEXANDROU, E. 2015). Their reconfiguration is closely connected to transformation processes of corresponding political and planning systems (Kaiser, R. and Prange, H. 2004; Hamidi, S. and Zandiatashbar, A. 2018). Historically, there have been major differences between countries in the ways in which they have organised and sustained innovation within their national economies (FreEmaN, C. 1995), where urban development has an important feedback effects (CARTER, R.A. 1988; Pumain, D. et al. 2009). HäGERstrand, T. (1952) was the first to formalize the propagation of innovation among towns and cities as a hierarchical diffusion process: the largest cities are the first to capture the benefit of the innovation, then the innovation filters down the urban hierarchy, according to urban size, through imitative or competitive processes: the larger cities adopting first, then the medium-sized cities, and later the smallest towns (cf. Pumain, D. et al. 2009).

The post-World War II saw a shift of population, businesses, and economic activity from 
the urban centres to the suburbs, the rise of the so-called edge cities of industry and technology at the suburban periphery, as well as a clustering of high technology enterprise, creative workforce and venture capital in suburban "nerdistans" (BontJe, M. and KePsu, K. 2013; Florida, R. and Mellander, C. 2016; Kozina, J. and Clifton, N. 2018). However, what we witness today is a movement of talent and jobs from the suburbs back to the city; a phenomenon occurring over the past decade or so defining that it will be the city - not the state - that gets to become the core of economic and political power (Markatou, M. and Alexandrou, E. 2015). The rank-size distribution of the creative class across 444 city regions in 8 European countries indicates a higher concentration in larger urban areas compared to smaller cities and towns (Lorenzen, M. and Vaarst Andersen, K. 2009). The suburban model might have been a historical aberration, and innovation, creativity, and entrepreneurship are realigning in the same urban centres that traditionally fostered them (Florida, R. and Mellander, C. 2016).

However, recent spatial trends in innovation have been well documented for large cities and metropolitan areas such as London and San Francisco (e.g. Ferrary, M. and Granovetter, M. 2009; Nathan, M. et al. 2012). On the other hand, little has been done to reflect the changing patterns of nationallevel urban hierarchy (Lu, L. and HuANG, R. 2012). There is a lack of direct evidence on how dispersed forms of settlement affect innovation productivity (HAmidi, S. and Zandiatashbar, A. 2018). Due to weak theoretical base and lack of clarity, evaluation of the research and formulation of guidelines for territorial innovation policies is limited, especially in small and medium-sized regions (Andersson, M. and Karlsson, C. 2006). To this end, we need a more pronounced evidence of how territorial policies shape the development of innovation, especially in medium-sized and small towns outside the reach of the agglomeration areas.

Territorial development of innovation in Central and Eastern Europe

The only comprehensive and comparable hard data to measure the creative economy and innovation across different countries are available from international organisations, such as the United Nations (UN, 2015). According to those reports, Slovenia's creative industries exports stood at USD 756.5 million in 2013, and imports reached USD 584.4 million, generating a positive trade balance of USD 172 million. Design (interior design and fashion) and publishing (newspaper and books) are the leading creative sectors in terms of exports. However, growth in the creative industries exports has been lagging in contrast to other CEE countries (Table 1), possibly since Slovenia was one of the hardest hit countries in the recent economic crisis (Verbič, M. et al. 2016). On the other hand, the number of patents in Slovenia is significantly higher, indicating perhaps a better innovation potential of the country. In other indicators pertaining to innovation, such as the quality of R\&D sector, tertiary education, and capacity of innovation, Slovenia together with

Table 1. Creative industries (CI) exports and number of applications filed under the Patent Cooperation Treaty $(P C T)$ in selected CEE countries

\begin{tabular}{l|c|c|c}
\hline \multirow{2}{*}{ Country } & \multicolumn{2}{|c|}{ CI exports, million USD } & $\begin{array}{c}\text { PCT per million } \\
\text { inhabitants, 2017 }\end{array}$ \\
\cline { 2 - 3 } & 2003 & 2013 & 24.4 \\
Czechia & $\mathrm{n} / \mathrm{a}$ & $\mathrm{n} / \mathrm{a}$ & 24.7 \\
Hungary & $2,161.35$ & $3,485.12$ & 10.5 \\
Poland & $2,687.71$ & $5,401.63$ & 11.3 \\
Slovakia & 667.75 & $1,354.15$ & 71.9 \\
Slovenia & 668.63 & 756.51 & \\
\hline
\end{tabular}

n/a = no data. Sources: World Economic Forum, 2018; UN, 2015. 
Czechia generally scores higher than other CEE countries (World Economic Forum 2018).

If we consider the copyright industry, which includes 31 sectors according to combined WIPO and USPTO methodology, it is an important economic sector in Slovenia. It employs 2.9 per cent of the workforce and contributes to 4.0 per cent of the overall GDP in Slovenia, while the EU average is 3.2 per cent in employment and 4.2 per cent in GDP respectively (Forum D'Avignon 2014). CEE countries are not that much different in this respect, with Czechia having the highest GDP share (4.5\%) and Hungary the highest employment share $(3.1 \%)$. Regardless if we look at the creative industries or the copyright industries, we can observe that they represent significant segments of economy in Slovenia and CEE as a whole, especially if we consider that they emerged practically from scratch only one or two decades ago (Stryjakiewicz, T. et al. 2014).

Although research in the creative economy is quite extensive, it is more difficult to find those focusing on spatial patterns and the impact of territorial policies on them. In Slovenia, the research is limited towards finding spatial patterns of employees in creative economy on a level of city-regions (Kozina, J. and Bole, D. 2017; Kozina, J. and Clifton, N. 2018). The main finding is that workplaces in the creative economy still cluster in main urban centres, which was already established by other research for instance in Italy and Spain (LAzZERETTI, L. et al. 2008). The creative economy tends to cluster in large urban areas, where it plays an important role for the local economic base. The findings from Slovenia reconfirm those results. But Slovenian results also show a slight shift of employees working in the creative economy towards more suburban and rural locations within the cityregional context in the last decade.

In other CEE countries, spatial patterns of the creative economy and innovation are also scarce. In Hungary, most of the creative labour is employed by foreign-owned companies in the north-western and north-eastern regions. There is also a high concentration of creative professionals in Budapest, due to historic trajectories where past uneven developmental policies created the capital city as a 'lone star' atop of the national urban system (Lengyel, B. and SÁgvári, B. 2011), which also holds true for some other countries such as Bulgaria and Serbia (Bontje, M. et al. 2011). Budapest on the other hand holds almost 43 per cent of the country's creative employees (Kovács, Z. et al. 2007; EgEdy, T. and Kovács, Z. 2009). A study from Czechia also confirms that the creative economy is unevenly spatially distributed with concentrations in large cities and especially Prague, which has almost 40 per cent of country's creative economy employment (SLACH, O. et al. 2013). Spatial patterns in Czechia follow the settlement hierarchy, where population density is in positive and traditional manufacturing in negative relationship with the localization of the creative economy.

In Poland, the data is neither available nor comparable with other countries, although there are some indices that the spatial patterns are less centralised (NAMYśLAK, B. 2013). According to KasprzaK, R. (2015), Warsaw is the place for the majority of the creative economy enterprises, but not to the same degree as in other CEE countries. Results from Slovakia are similar to other CEE countries, displaying a strong concentration in larger cities, especially Bratislava and Košice but with recent slight de-concentration tendencies in the past years (BLAhovec, R. and Hudec, O. 2012; RенÁк, Š. et al. 2014). In Romania, the distribution of creative economy follows the urban hierarchy, with Bucharest having a dominant role, expressed with a higher density of companies and employees in the creative economy (Pintiliı, R.D. et al. 2017).

Spatial patterns of the creative economy in CEE countries exhibit higher concentration in capital cities or capital metropolitan regions. Ljubljana, Budapest and Prague all have between $40-45$ per cent of the total national employment in the creative economy in their respective countries. This was established also in other non-CEE countries: 77 
per cent of all creative clusters are found in metropolitan regions (Borx, R. et al. 2015). This concentration in large or capital cities could be explained by theories of agglomeration economies: co-location of firms and their spatial proximity, availability to specialised firms and services and access to knowledge spill-overs (Lorenzen, M. and FrederiKsen, L. 2007; Hamidi, S. and Zandiatashbar, A. 2018). In addition to the benefits provided by agglomeration economies, the creative economy also clusters due to the mechanisms of spin-off formation (especially universities and of creative private firms) and institutional support (Gong, H. and Hassink, R. 2017). This institutional support in the form of public sector initiatives such as special trainings, public funding, higher education activities, and policies orientated towards strengthening the role of the creative economy are thus active agents in spatial distribution of creativity.

\section{Research context and design}

Territorial policies and urban development in Slovenia

The main aim of territorial policies (spatial and developmental plans and strategies, urban and regional plans) after the World War II was to establish polycentric urban development system. Most of this has been achieved through two local government reforms in 1960s/1970s and 1990s. Before the World War II, there were 469 municipalities in Slovenia. Their number constantly decreased to 62 in 1964 (Figure 1). This was a one-tier system and was mostly understood as an extension of the state power (NARED, J. 2018). The rationale of such territorial development was to develop centres that would be equally divided and would provide the same possibilities for work, living, recreation and social standing to all inhabitants. This idea suited the economic, social and ideological circumstances of socialism (NARED, J. 2018). About 13-15 towns would form the frame of

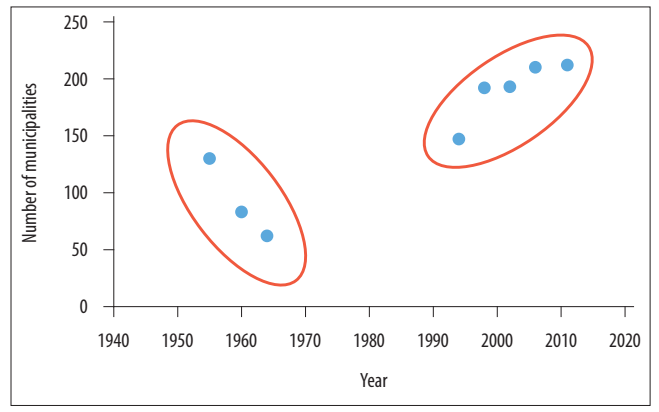

Fig. 1. Spatial concentration and dispersion of the local (self)government system after the World War II and the independence of Slovenia. Source: NARED, J. 2018

such polycentric development (a more precise number was not set). In 1974, the new constitution of Yugoslavia identified municipalities as not only administrative but also the economic units. Instead of 13-15 regional centres, there were suddenly 64 centres (the same as the number of municipalities) (DrozG, V. 2012). Such urban development system strongly favoured small towns with population between 5,000 and 20,000.

The second major local government reform took place after the independence of Slovenia in 1991, when the number of municipalities started to increase again from previous 62 to 212 in 2011 (NARED, J. 2018). The vast majority of newly born municipalities were established in a rural context. The introduction of new municipalities signalled the discontinuation of the previous local government system in which the municipality, as a 'socio-political community', primarily operated in the name of the state while the exercise of local self-government mostly took place within smaller local communities (ČOKERT, A. 2005). This policy recognised two spatial levels of government: the local (municipal) and state level, whereas the regional level is only administrative. The Spatial Development Strategy of Slovenia from 2004 (Figure 2) identified 15 regional centres (urban centres of national importance) but no further steps were made towards establishing a second- 


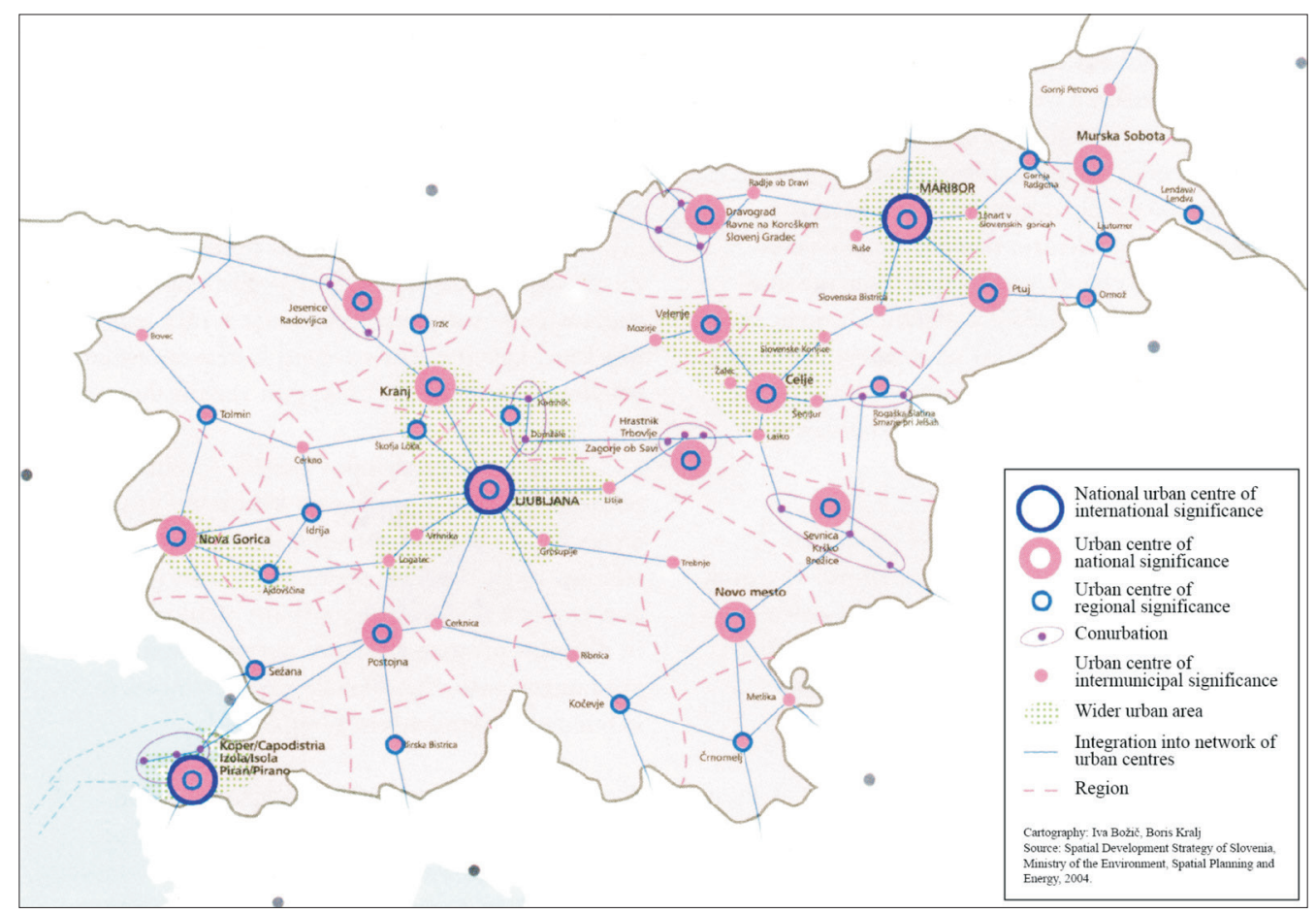

Fig. 2. Polycentric urban system and development of wider urban areas in Slovenia in 2004. Source: MOPE, 2004.

tier level of government system. Such territorial development exacerbated the unevenness of the Slovenian urban system, which is reflected in the lack of regional centres or medium-sized towns with population above 50,000 , a strong presence of small towns below 20,000 inhabitants that typically display 'oversupply' of public services and functions in comparison to medium-sized towns (NARED, J. et al. 2017), and high prevalence of rural centres.

\section{Methodology}

With an aim to study the impact of territorial policies on the distribution of innovation in the Slovenian urban system, we analysed spatial-temporal trends of patents granted per place of patent holder between 1975 and 2014. The data were obtained from the Slovenian In- tellectual Property Office. Empirical confirmation of the powers of spatial agglomeration in regard to knowledge generation can be found in the empirical works of JAFFE, A.B. et al. (1993), ÓHUALlacháin, B. (1999), Acs, Z.J. et al. (2002), Crescenzi, R. et al. (2007) and others on the geography of patenting. They suggest that patenting activities are typically concentrated in agglomerated centres of production. Patent statistics provide a measure of innovative output. Their strength is to provide comparable information on inventions across a broad range of technological sectors (CRESCENZI, R. et al. 2007) and are available in large numbers and for a very long time series (ARCHibugi, D. 1992), which is of utmost importance when conducting such spatial-temporal analysis. The number of patents has been linked to $R \& D$ activity and to innovation, and is therefore a widely used indicator of the capacity of a region to exploit knowledge and to translate it 
into potential economic gains (Bowen, H.P. et al. 2008). Patent statistics is probably the most commonly used empirical indicator for the innovative output of firms and regions (BRENNER, T. and Broekel, T. 2011).

However, patent indicators also suffer from a number of limitations in their ability to proxy innovation, and hence must be interpreted with care (CRESCENZI, R. et al. 2007). Patents are notably troublesome, because not all innovations are patented, and not all patents are equally innovative or rewarding (Sсотт, A.J. 2006). To overcome these barriers, other more complex approaches can be applied such as R\&D and non-R\&D activities, innovation surveys and other intellectual property records (Lhuillery, S. et al. 2016). However, Acs, Z.J. et al. (2002) and Crescenzi, R. et al. (2007) claim that patent statistics return results highly comparable with other measures, thus allowing us to consider the growth rate of patents as an effective proxy for measuring spatial patterns of innovation.

Spatial units of analyses are 212 municipalities, which correspond to Local Administrative Units (LAU level 2) according to the Nomenclature of Territorial Units for Statistics (NUTS) of EUROSTAT. The municipalities are divided into four main groups according to the period of their establishment that highly corresponds with the urban hierarchy level. In addition, we distinguish older 62 municipalities into Ljubljana as the capital and the only large city in the country $(\sim 290,000$ inhabitants in 2016); regional centres (foreseen as a backbone of the urban system in the 1960s, identified as urban centres of national significance by the Spatial Development Strategy of Slovenia in 2004, but never established as capitals of regional authority units) and other small towns (Table 2).

\section{Results: territorial dynamics of innovation in Slovenia}

The innovation activity measured through the patents granted was almost insignificant in Slovenia until 1991, when the country gained independence from Yugoslavia and entered the market economy (Figure 3). The situation was therefore the same as in other post-socialist countries that were described as 'complete deserts in terms of innovation and business networks' (STRYJAKIEWICZ, T. et al. 2014). Further developments were in line with the prevailing trends in economic development: moderate and sustained growth after 1991, a re-acceleration shortly after the entry into the European Union in 2004 and a sharp decline after 2011, when the delayed effects of the global recession began to intensify in Slovenia (Verbič, M. et al. 2016).

Table 2. The structure of municipalities according to the period of establishment, the dominant type of municipal centres and size

\begin{tabular}{l|l|l|r|r|r|r|r}
\hline \multicolumn{2}{c|}{ Type of municipalities } & \multicolumn{4}{c}{ Population in 2016 } \\
\hline \multicolumn{2}{c}{ Period of establishment } & $\begin{array}{l}\text { Dominant type of } \\
\text { municipal centres }\end{array}$ & N & Mean & SD & Min. & Max. \\
\hline \multirow{3}{*}{$1964-1994$} & Capital city* $^{*}$ & Large city & 1 & $/$ & $/$ & $/$ & $/$ \\
& Regional centres** & Medium-sized town & 23 & 28,157 & 22,408 & 8,885 & 111,832 \\
& Other & Small town & 34 & 14,375 & 6,682 & 4,056 & 35,278 \\
\hline $1994-1998$ & Rural centre & 89 & 4,977 & 2,856 & 372 & 16,182 \\
$1998-2006$ & Rural centre & 45 & 3,021 & 2,191 & 375 & 11,273 \\
$2006-2011$ & Rural centre & 20 & 3,032 & 952 & 2,039 & 5,515 \\
Total & & 212 & 9,737 & 22,260 & 372 & 288,307 \\
\hline
\end{tabular}

${ }^{*}$ Ljubljana was divided into five municipalities in 1964. They were merged in 1994. ${ }^{*}$ The Spatial Development Strategy of Slovenia identified some medium-sized towns as conurbations. These are BrežiceKrško-Sevnica, Jesenice-Radovljica, Koper-Izola-Piran, Slovenj Gradec-Ravne na Koroškem-Dravograd, and Trbovlje-Hrastnik-Zagorje ob Savi. However, in present paper we analyse them separately. Source: Authors' calculation based on the data of the Statistical Office of the Republic of Slovenia. 


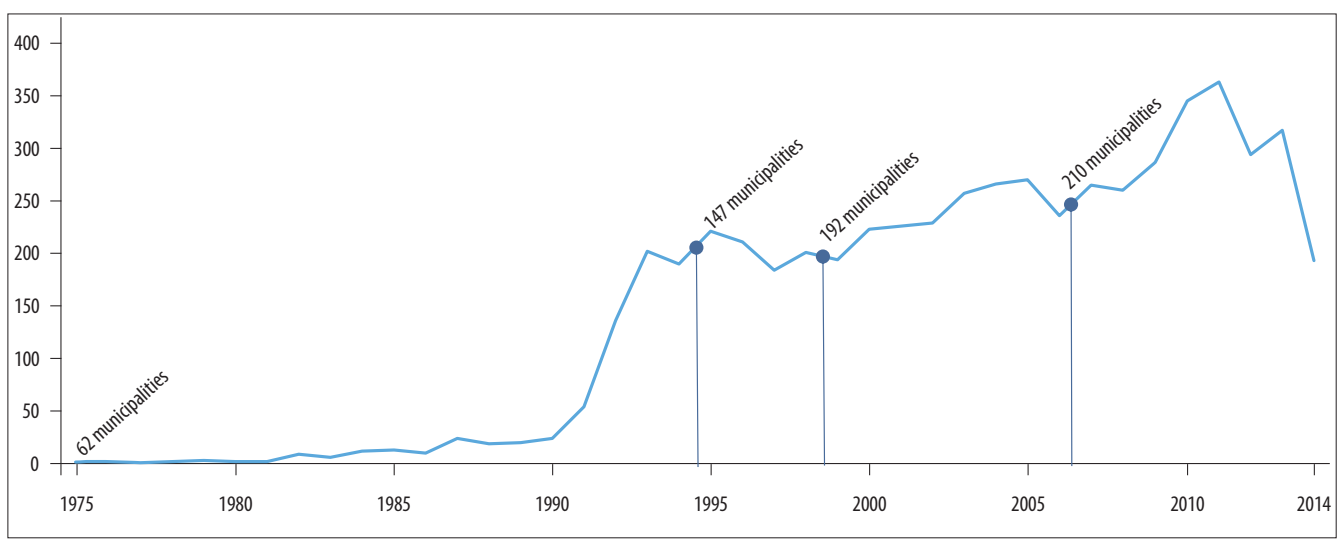

Fig. 3. Evolution of patents granted between 1975 and 2014 in Slovenia. Source: The Slovenian Intellectual Property Office.

Spatial distribution of patents granted between 1975 and 2014 according to urban hierarchy outlines strong concentration in Ljubljana as the only large city with 31.2 per cent of all granted patens (Figure 4). Stronger concentration can also be detected in some medium-sized towns such as Maribor, Kranj, Velenje, Novo mesto, Celje and Koper, whereas many of them portray a similar image as small towns and in some cases even rural centres. Innovation distribution does not necessarily follow the agglomerative logic in a straightforward way as suggested by empirical works of JAFFE, A.B. et al. (1993), ÓhUallacháin, B. (1999), Acs, Z.J. et al. (2002), CrescenzI, R. et al. (2007).

Between 1994 and 2014, innovation activity increased at the national level by 2.5 times. It is important to note that there was a significant increase in all types of municipalities. However, the largest increase was recorded in small towns (3.9 times) and rural areas (3.4-3.7 times), significantly smaller in medium-sized towns (2.5 times) and the smallest in the capital city of Ljubljana (1.7 times). Innovation has therefore intensified the most in less urbanized settlements (Table 3).

Ljubljana as the capital city is constantly losing its position as the innovation leader. From more than one third of patents granted in 1994 this share fell to almost 25 per cent in 2014. The medium-sized towns have kept their constant position, while small towns that were granted local authority rights in 1960s/1970s, on the one hand, and newly established rural municipalities after 1994, on the other hand, have improved their position. Territorial policies from the socialist and post-socialist era favouring polycentricism at lower hierarchical levels and neglecting regional centres have influenced also a more even distribution of innovation activities.

Dispersion of innovation activities can also be detected within individual categories of municipalities. Gini coefficients exhibit continuous dispersion in the categories of small towns and rural centres. Medium-sized towns remain quite stable in this regard. However, the concentration is generally a bit higher in rural rather than urban context (see Table 3).

\section{Discussion and conclusions}

The objective of this paper is to study the impact of territorial policies on the distribution of the creative economy in Slovenia as an example of the post-socialist country. By analysing spatial-temporal trends of patents 


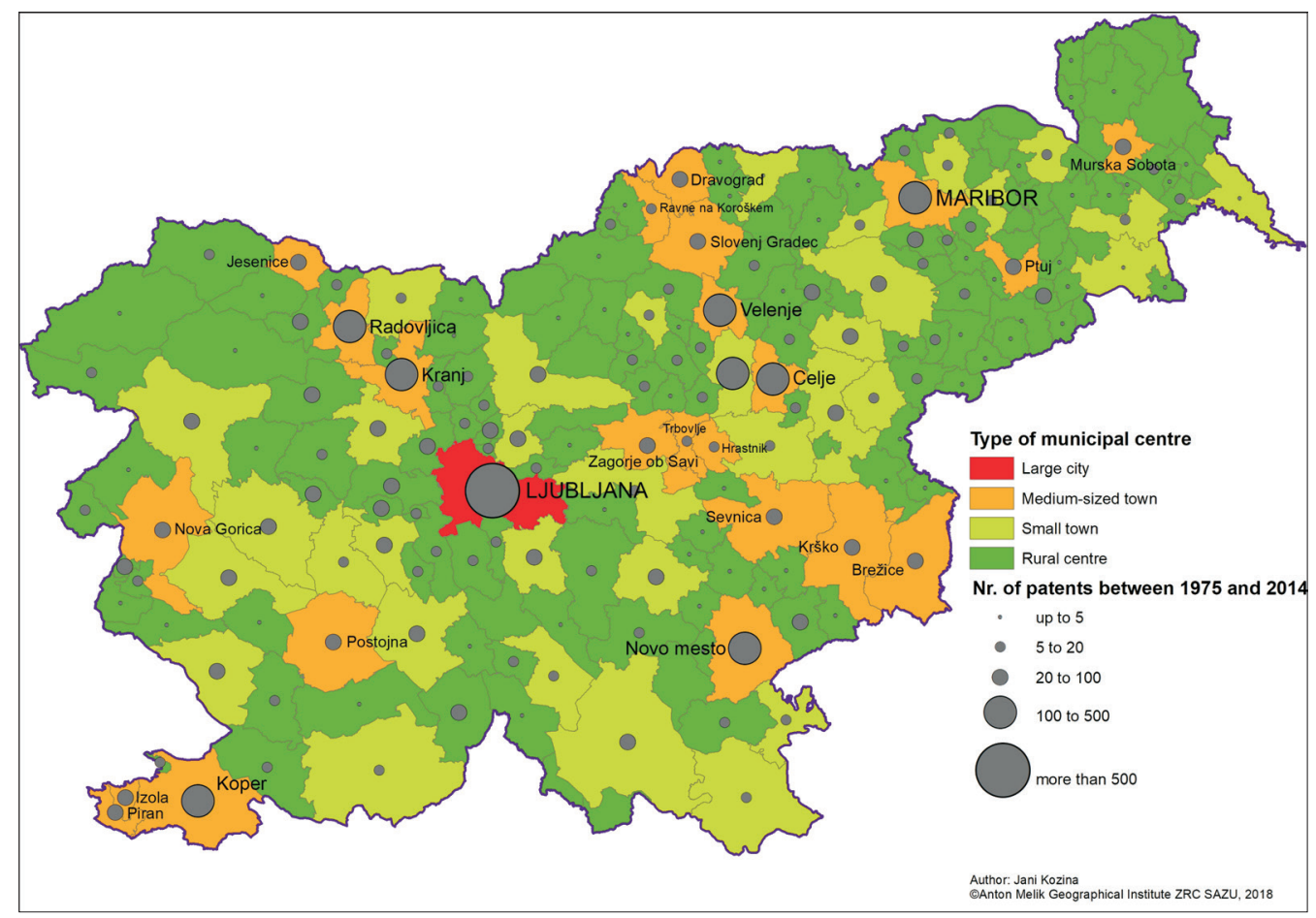

Fig. 4. Spatial distribution of patents granted between 1975 and 2014 according to urban hierarchy in Slovenia. Source: The Slovenian Intellectual Property Office.

granted, we aim to track patterns of innovation between 1975 and 2014 in the urban system. A central focus is given to examine changes in urban hierarchy, i.e. relationships between Ljubljana as the capital and the only large city in the country, regional centres or medium-sized towns and small towns.

Spatial-temporal analysis of patents granted in Slovenia confirms the linkages between territorial innovation systems and changes in the urban system. The main findings show that innovation has become more evenly distributed across space, which can be attributed to long tradition of polycentric spatial development in times of Yugoslavia and more recent territorial policies favouring further devolvement of power from the regional level to local municipal centres. This means that municipal centres that gained decision-making and administrative importance gradually also increased their innovation potential. The results are consistent with the outcomes of other authors who highlight the connection between reconfiguration of territorial innovation systems and transformation processes of corresponding political and planning systems (Kaiser, R. and Prange, H. 2004; Hamidi, S. and Zandiatashbar, A. 2018).

However, to say that patterns of innovation are becoming uniformly distributed across the urban system would be an exaggeration. A better description is that territorial polices can, over a longer period, 'nudge' spatial patterns of innovation into a specific direction or shape. In Slovenian case, towards a slightly more balanced, polycentric structure by favouring small towns, which were designated as central settlements in 1960s/1970s, and rural centres, which were given a more important role in the settlement structure after 1994 


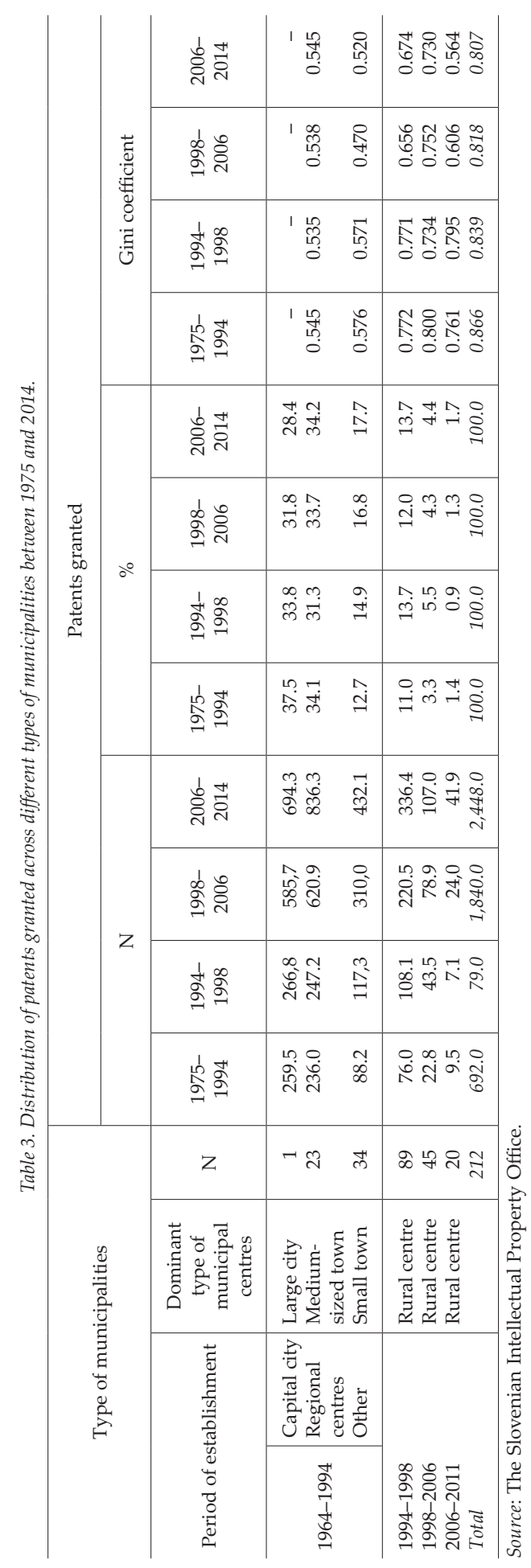

(NARed, J. 2018). Territorial tendencies of innovation follow a similar pattern of a slight shift of employees working in the creative economy towards more suburban and rural locations within the city-regional context in the last decade (KozinA, J. and Bole, D. 2017; Kozina, J. and Clifton, N. 2018). This nudge may be related to the impact of local (self)government reforms affecting improvement of some public service (e.g. education, health, administration), which are strongly linked to greater territorial innovation potential (Doloreux, D. 2002; Morgan, K. 2004). Being a municipal centre in Slovenia guarantees better access to public services, which leads to better living and working environment (NARED, J. 2018) and possibly also to a better innovation potential of those localities. In the socialist era, newly established municipal centres were further developed with new economic functions - for instance, every town was 'equipped' with at least one industrial plant, an accompanying apartment buildings built for industrial workers, and basic social infrastructure (DrozG, V. 2012). We could argue that although the transition to market economy transformed and deindustrialised those smaller centres, they retained the 'pioneering' spirit, defined as a range of certain assets like mind-sets, skills, traditions and tacit knowledge (HARFST, J. et al. 2018), which is so important for the creative economy. This is also a demonstration of how territorial polices can influence the innovation systems through improving amenities in the public sector domain.

Nevertheless, the spatial structure of innovation activities still reflects the dominant agglomeration logic and follows urban hierarchy. Just as in the case of employees working in the creative economy (KozInA, J. and Bole, D. 2017; Kozina, J. and Clifton, N. 2018), patents granted also concentrate in larger and more central settlements in the urban system. Ljubljana as the capital and the only large city in the country with $\sim 290,000$ inhabitants in 2016 still exhibit the supremacy over other medium-sized and small towns, although its fading role does not ultimately 
legitimise anymore a status of a 'lone star' atop of the national urban system, which is so typical for other capital cities in CEE (KovÁcs, Z. et al. 2007; EgEdy, T. and KovÁcs, Z. 2009; Bontje, M. et al. 2011; Lengyel, B. and SÁgvári, B. 2011; SLACH, O. et al. 2013) and also metropolitan areas of non-CEE countries (Boix, R. et al. 2015). The fading role of Ljubljana could probably be explained by higher land and property values, which can be a significant discouraging locational factor for small innovative businesses (HAMIDI, S. and Zandiatashbar, A. 2018).

Medium-sized towns ( 20,000-50,000 inhabitants) maintain their innovative role stagnant, although growth would be expected in line with their 'assigned' role in the Spatial Development Strategy of Slovenia from 2004, where they are defined as centres of national significance. The role of mediumsized towns in the national innovation system can be explained by the spatial policy, where the regional level is neglected, nonautonomous, and where, from a public administration point of view, regional centres have exactly the same competences as the local municipal centres (NARED, J. 2018). On the other hand, small towns ( 5,000-20,000 inhabitants), which were defined as central places in 1960s/1970s, exhibit the largest growth of innovation activities. They are probably using their 'oversupply' with social and physical infrastructure as a competitive advantage contrary to larger urban environments in attracting, retaining and/or releasing innovation potential. As shown by NARED, J. et al. (2017), small towns are also very important in terms of export orientation and global competitiveness of Slovenia since they are the location of successful export orientated companies both from the socialist and post-socialist era.

This research contains certain limitations, which relate to the ability of patent indicators to proxy innovation. Such limitations include the heterogeneous value or degree of novelty of patented products or processes, non-patentability of many inventions or the better cost-effectiveness of other protection methods (e.g. secrecy), the different propensity to patent across countries and sectors (Archibugi, D. 1992). However, Acs, Z.J. et al. (2002) and Crescenzi, R. et al. (2007) argue that analyses based on patent counts deliver results highly comparable with those based on more direct measures of innovation, thus allowing us to consider the growth rate of patents as an effective proxy for changes in local innovative performance.

Patents can thus be a measure of both the creative economy and innovation. By including patents and other measures of territorial innovations systems, we can contribute to the methodological pluralism in the creative economy research and unveil its hidden perspectives. It would be interesting to see if other countries with similar polycentric structure and/or policies as Slovenia (e.g. Switzerland, Germany, Poland, the Netherlands) also exhibit similar territorial innovation patterns. In addition, it would be interesting to know which aspects of territorial policies influence the innovation system the most: is it the infrastructure (construction of physical or social space) or the more indirect aspects (institutional support for innovations, the innovative milieu etc.)? This research tried to focus on untapped synergies between innovation, policies and space. New findings may serve planners and policy makers to be better equipped to create places that not only benefit industry clusters, but that provide the framework for more robust territorial innovation systems (Hamidi, S. and Zandiatashbar, A. 2018).

Acknowledgement: This work was supported by the Slovenian Research Agency (ARRS) under program P6-0101 Geography of Slovenia and grant H6-8284 (B) awarded to the JPI Urban Europe project "Bright Future for Black Town". 


\section{REFERENCES}

Acs, Z.J., Anselin, L. and Varga, A. 2002. Patents and innovation counts as measures of regional production of new knowledge. Research Policy 31. (7): 1069-1085.

Andersson, M. and Karlsson, C. 2006. Regional Innovation Systems in Small and MediumSized Regions. In The Emerging Digital Economy: Entrepreneurship, Clusters, and Policy. Eds.: Johansson, B., Karlsson, C. and Stough, R., Berlin, Springer, 55-81.

Archibugi, D. 1992. Patenting as an indicator of technological innovation: a review. Science and Public Policy 19. (6): 357-368.

BaKhshi, H. and McVittie, E. 2009. Creative supplychain linkages and innovation: Do the creative industries stimulate business innovation in the wider economy? Innovation: Management, Policy $\mathcal{E}$ Practice 11. (2): 169-189.

Bell, W. 1973. The Coming of Post-Industrial Society. New York, Basic Books.

Blahovec, R. and Hudec, O. 2012. Employment Analysis in the Creative Industries in Slovakia: Spatial and Temporal Evolution in the Years 2001-2010. Region Direct 2012. (2): 58-89.

Boggs, J. 2009. Cultural Industries and the Creative Economy - Vague but Useful Concepts. Geography Compass 3. (4): 1483-1498.

Boix, R., Hervás-Oliver, J.L. and De MiguelMolinA, B. 2015. Micro-Geographies of Creative Industries Clusters in Europe: From Hot Spots to Assemblages: Micro-Geographies of Creative Industries Clusters. Papers in Regional Science 94. (4): 753-72.

Bontje, M. and Kepsu, K. 2013. Creative Knowledge Strategies for Polycentric City-Regions. In Placemaking and policies for competitive cities. Eds.: Musterd, S. and Kovács, Z., Oxford, WileyBlackwell, 191-208.

Bontje, M., Musterd, S. 2009. Creative industries, creative class and competitiveness: Expert opinions critically appraised. Geoforum 40. (5): 843-852.

Bontje, M., Musterd, S., Kovács, Z. and Murie, A. 2011. Pathways Toward European CreativeKnowledge City-Regions. Urban Geography 32. (1): 80-104.

Boschma, R.A. and Fritsch, M. 2009. Creative Class and Regional Growth: Empirical Evidence from Seven European Countries. Economic Geography 85. (4): 391-423.

Bowen, H.P., Moesen, W. and Sleuwaegen, L. 2008. A Composite Index of the Creative Economy. Review of Business and Economic and Literature 0(4). 375-397.

Brenner, T. and Broekel, T. 2011. Methodological Issues in Measuring Innovation Performance of Spatial Units. Industry and Innovation 18. (1): 7-37.
CARTER, R.A. 1988. Innovation in urban systems: The interrelationships between urban and national economic development. The Annals of Regional Science 22. (3): 66-79.

Chapain, C., Clifton, N. and Comunian, R. 2013. Understanding Creative Regions: Bridging the Gap between Global Discourses and Regional and National Contexts. Regional Studies 47. (2): 131-134.

ČoKert, A. 2005. Teritorialni del reforme lokalne samouprave $\mathrm{v}$ sloveniji (Territorial part of the reform of local self-government in Slovenia). Dela 24. 207-217.

Collins, P. and Cunningham, J.A. 2017. Creative Economies in Peripheral Regions. Cham, Palgrave Macmillan.

Crescenzi, R., Rodríguez-Pose, A. and Storper, M. 2007. The territorial dynamics of innovation: a Europe-United States comparative analysis. Journal of Economic Geography 7. (6): 673-709.

Cunningham, S.D. 2007. The Creative Economy: Patterning the Future. Dialogue: Academy of the Social Sciences in Australia 26. (1): 15-23.

Doloreux, D. 2002. What we should know about regional systems of innovation. Technology in Society 24. (3): 243-263.

DrozG, V. 2012. Polycentric Urban System Between State Regulation and Market Economy - The Case of Slovenia. In Development of the Settlement Network in the Central European Countries. Eds.: Csapó, T. and BALOGH, H., Berlin, Springer, 3-12.

Egedy, T. and Kovács, Z. 2009. The capacity and potentials of Budapest to attract creative economy. Hungarian Geographical Bulletin 58. (4): 281-294.

European Commission 2010. Green Paper - Unlocking the potential of cultural and creative industries. https:// www.hhs.se/contentassets/3776a2d6d61c4058ad564 713cc554992/greenpaper_creative_industries_en.pdf Accessed on 20.06.2018.

Eurostat 2017. The new urban rural typology. http:// ec.europa.eu/eurostat/statistics-explained/index. php/Urban-rural_typology\#The_new_typology Accessed on 12.07.2017.

Ferrary, M. and Granovetter, M. 2009. The role of venture capital firms in Silicon Valley's complex innovation network. Economy and Society 38. (2): 326-359.

Florida, R. 2002. The Rise of the Creative Class: And How It Is Transforming Work, Leisure, Community and Everyday Life. New York, Basic Books.

Florida, R. and Mellander, C. 2016. Rise of the Startup City: The Changing Geography of the Venture Capital Financed Innovation. California Management Review 59. (1): 14-38.

Florida, R., Adler, P. and Mellander, C. 2017. The city as innovation machine. Regional Studies 51. (1): 86-96.

Forum D'Avignon 2014. The economic contribution of the creative industries to EU GDP and employment: Evolution 2008-2011. https://ec.europa.eu/futu- 
rium/en/content/economic-contribution-creativeindustries-eu-terms-gdp-and-jobs Accessed on 17.05.2018.

FreEman, C. 1995. The 'National System of Innovation' in historical perspective. Cambridge Journal of Economics 19. (1): 5-24.

Garnham, N. 2005. From cultural to creative industries. International Journal of Cultural Policy 11. (1): 15-29.

Gong, H. and Hassink, R. 2017. Exploring the Clustering of Creative Industries. European Planning Studies 25. (4): 583-600.

Hägerstrand, T. 1952. The propagation of innovation waves. Lund, The Royal University of Lund.

Hamidi, S. and Zandiatashbar, A. 2018. Does urban form matter for innovation productivity? A national multi-level study of the association between neighbourhood innovation capacity and urban sprawl. Urban Studies 55. (1): 1-19.

Harfst, J., Wust, A. and NadLER, R. 2018. Conceptualizing industrial culture. GeoScape 12. (1): 1-9.

Hollanders, H. and Es-Sadki, N. 2017. Regional Innovation Scoreboard 2017. https://ec.europa.eu/ growth/industry/innovation/facts-figures/regional_en Accessed on 21.06.2018.

Hong, J., Yu, W., Guo, X. and Zhao, D. 2014. Creative industries agglomeration, regional innovation and productivity growth in China. Chinese Geographical Science 24. (2): 258-268.

Howkins, J. 2001. The Creative Economy: How People Make Money from Ideas. Harmondsworth, Penguin Books.

Jaffe, A.B., Trajtenberg, M. and Henderson, R. 1993. Geographic Localization of Knowledge Spillovers as Evidenced by Patent Citations. The Quarterly Journal of Economics 108. (3): 577-598.

Kaiser, R. and Prange, H. 2004. The reconfiguration of National Innovation Systems - the example of German biotechnology. Research Policy 33. (3): 395-408.

KasprzaK, R. 2015. Creative Industries in The Polish Economy. Quaestiones Geographicae 34. (2): 35-43.

Kern, P. (ed.) 2015. The Smart Guide to Creative Spillovers. http://www.keanet.eu/wp-content/uploads/ SMARTGUIDE-FINAL-PDF.pdf?4f4eb7 Accessed on 20.06.2018.

Kovács, Z., Egedy, T., Földi, Z., Keresztély, K. and Szabó, B. 2007. From State Socialism to Global Capitalism: Budapest on the Way to Creative and Knowledge-Based Cities. 2.4. ACRE Report. Amsterdam, AMIDSt, University of Amsterdam.

Kozina, J. and Bole, D. 2017. Creativity at the European Periphery: Spatial Distribution and Developmental Implications in the Ljubljana Region. In Creative Industries in Europe: Drivers of New Sectoral and Spatial Dynamics. Eds.: Chapain, C. and Stryjakiewicz, T., Cham, Springer, 227-254.

KozinA, J. and Clifton, N. 2018. City-region or urbanrural framework: what matters more in understand- ing the residential location of the creative class? Acta Geographica Slovenica 59. (1): in press.

Landry, C. 2000. The Creative City: A toolkit for urban innovators. London, Earthscan.

Lazzeretti, L., Boix, R. and Capone, F. 2008. Do Creative Industries Cluster? Mapping Creative Local Production Systems in Italy and Spain. Industry and Innovation 15. (5): 549-67.

Lazzeretti, L., Capone, F. and Innocenti, N. 2018. The rise of cultural and creative industries in creative economy research: a bibliometric analysis. In Creative Industries and Entrepreneurship. Eds.: LAzzeretTI, L. and Vecco, M., Cheltenham, Edward Elgar Publishing, 13-34.

Lee, N. and Rodríguez-Pose, A. 2014. Creativity, cities, and innovation. Environment and Planning A 46. (5): 1139-59.

LENGYEL, B. and SÁgváRI, B. 2011. Creative Occupations and Regional Development in Hungary: Mobility of Talent in a One-Centred Transition Economy. European Planning Studies 19. (12): 2073-2093.

Lhuillery, S., Raffo, J. and Hamdan-Livramento, I. 2016. Measuring Creativity: Learning from Innovation Measurement. Economic Research Working Paper 31. $1-24$.

Lorentzen, M. and Frederiksen, L. 2007. Why do cultural industries cluster? Localization, urbanization, products and projects. In Creative cities, cultural clusters and local economic development. Eds.: CoOKE, P. and Lazzeretti, L., Cheltenham, Edward Elgar Publishing, 155-179.

Lorenzen, M. and VaArst Andersen, K. 2009. Centrality and Creativity: Does Richard Florida's Creative Class Offer New Insights into Urban Hierarchy? Economic Geography 85. (4): 363-390.

LU, L. and HUANG, R. 2012. Urban hierarchy of innovation capability and inter-city linkages of knowledge in post-reform China. Chinese Geographical Science 22. (5): 602-616.

Markatou, M. and Alexandrou, E. 2015. Urban System of Innovation: Main Agents and Main Factors of Success. Procedia - Social and Behavioral Sciences 195. 240-250.

Ministry of the Environment, Spatial Planning and Energy (MOPE). 2004. Spatial Development Strategy of Slovenia. http://www.mop.gov.si/fileadmin/mop. gov.si/pageuploads/podrocja/prostorski_razvoj/ SPRS_angleska_verzija.pdf Accessed on 29.08.2018.

Morgan, K. 2004. The exaggerated death of geography: learning, proximity and territorial innovation systems. Journal of Economic Geography 4. (1): 3-21.

Müller, K., Rammer, C. and Trüby, J. 2009. The role of creative industries in industrial innovation. Innovation: Management, Policy \& Practice 11. (2): 148-168.

Musterd, S. and Gritsai, O. 2012. The creative knowledge city in Europe: Structural conditions and urban policy 
strategies for competitive cities. European Urban and Regional Studies 20. (3): 343-359.

Musterd, S. and Kovács, Z. (ed.) 2013. Place-making and policies for competitive cities. Oxford, WileyBlackwell.

Musterd, S. and Murie, A. (ed.) 2010. Making competitive cities. Oxford, Wiley-Blackwell.

Namyślak, B. 2013. Creative Clusters in Poland. Barometr Regionalny 11. (2): 25-31.

Nared, J. 2018. Local Self-government Reforms in Slovenia: Discourse on Centrality and Peripherality. In Nature, Tourism and Ethnicity as Drivers of (De) Marginalization. Eds.: Pelc, S. and Koderman, M., Cham, Springer, 243-256.

Nared, J., Bole, D., Valjavec, M.B., Ciglič, R., GolužA, M., Kozina, J. and Istenič, M.Č. 2017. Central settlements in Slovenia in 2016. Acta Geographica Slovenica 57. (2): 7-32.

Nathan, M., Vandore, E. and Whitehead, R. 2012. A Tale of Tech City: The Future of Inner East London's Digital Economy. London, Centre for London.

Newbigin, J. 2010. The Creative Economy: An Introductory Guide. London, British Council.

ÓhUallacháin, B. 1999. Patent Places: Size Matters. Journal of Regional Science 39. (4): 613-636.

Pintilit, R.D., Peptenatu, D., Ciobotaru, A.M., Toma, S.G., Grigore, A.M., Drăghici, C.C., Dobrea, R.C., Simion, A.G., Andronache, I., Teodorescu, C. and DiAconU, C.D. 2017. Creative economies in Romania - spatial projections and trends. Bulletin of Geography. Socio-economic Series 37. (37): 95-108.

Pumain, D., Paulus, F. and Vacchiani-Marcuzzo, C. 2009. Innovation Cycles and Urban Dynamics. In Complexity Perspectives in Innovation and Social Change. Eds.: Lane, D., Pumain, D., van Der Leeuw, S.E. and West, G., Dordrecht, Springer, 237-260.
ReHÁk, Š., MaIer, G. and Bučé, M. 2014. The Spatial Pattern of Creative Industries in a Transformation Economy: The Case of Slovakia. Mitteilungen Der Österreichischen Geographischen Gesellschaft 155. 195-219.

SCHLEsINGER, P. 2016. The creative economy: invention of a global orthodoxy, Innovation: The European Journal of Social Science Research 30. (1): 73-90.

Scotт, A.J. 2006. Creative Cities: Conceptual Issues and Policy Questions. Journal of Urban Affairs 28. (1): 1-17.

Scott, A.J. and Storper, M. 2014. The Nature of Cities: The Scope and Limits of Urban Theory. International Journal of Urban and Regional Research 39. (1): 1-15.

Slach, O., Koutsky, J., Novotny, J. and ŽEnKa, J. 2013. Creative industries in the Czech Republic: a spatial perspective. Ekonomie 16. (4): 14-29.

Stryjakiewicz, T., Męczyński, M. and Stachowiak, K. 2014. Role of Creative Industries in the PostSocialist Urban Transformation. Quaestiones Geographicae 33. (2): 19-35.

UN 2015. Creative economy outlook and country profiles: trends in international trade in creative industries. Geneva, United Nations Conference on Trade and Development.

Verbič, M., Srakar, A., Majcen, B. and ČoK, M. 2016. Slovenian public finances through the financial crisis. Teorija in praksa 53. (1): 203-227.

World Economic Forum 2018. Global competitiveness index 2017-2018 reports. http://reports.weforum. org/global-competitiveness-index-2017-2018/competitiveness-rankings/\#series=EOSQ119 Accessed on 17.05.2018. 
